\title{
ALBUM OF MAPS
}

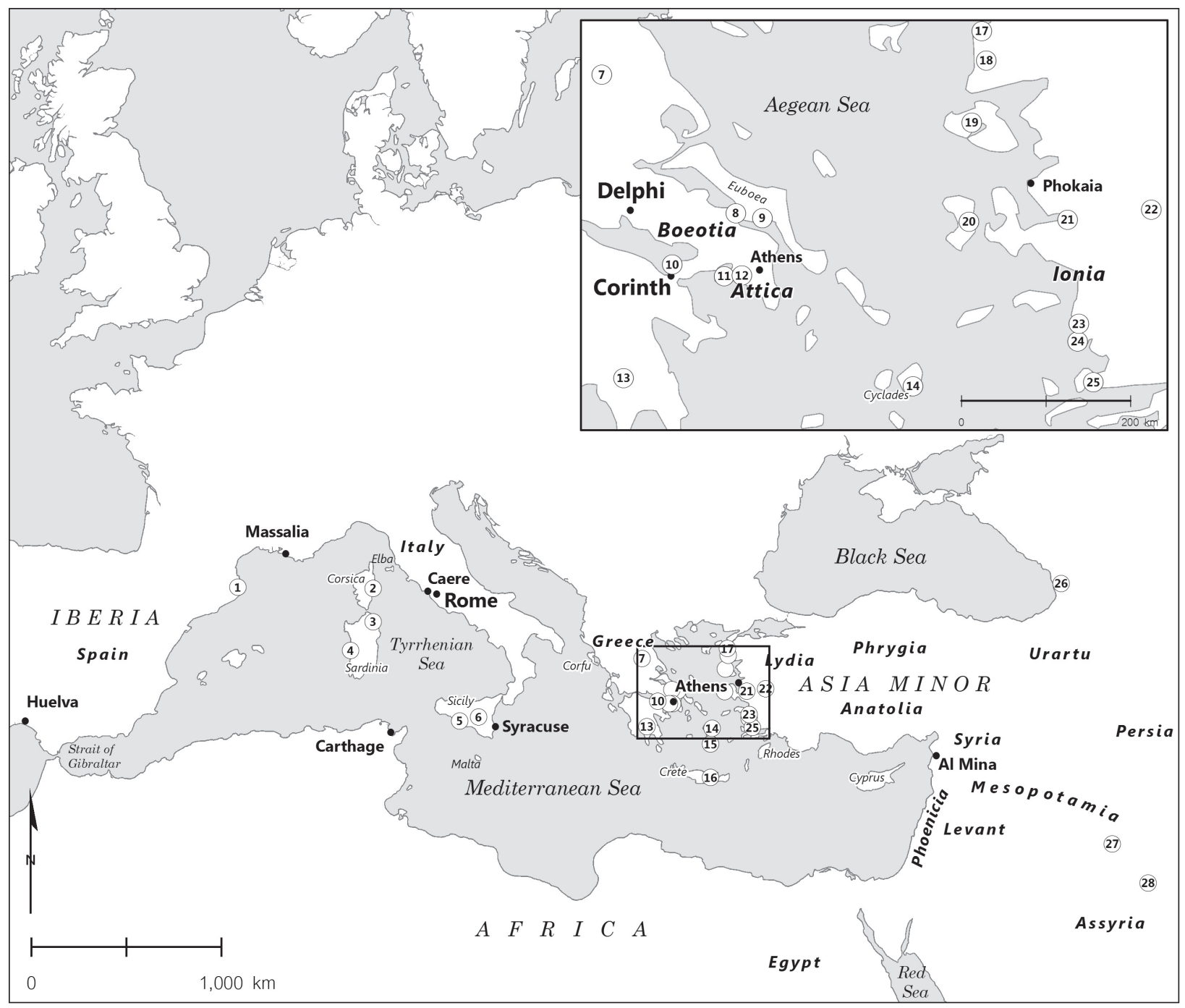

MAP I. The Mediterranean.

Numbered sites (roughly left to right): I. Ampurias; 2. Alalia; 3. Olbia; 4. Tharros; 5. Agrigento; 6. Morgantina; 7. Thessaly; 8. Khalkis; 9. Eretria; Io. Perachora; II. Salamis; I2. Piraeus; I3. Sparta; I4. Naxos; I5. Thera; I6. Malles; I7. Troy; I8. Neandria; 19. Lesbos; 20. Chios; 21. Larisa am Hermos; 22. Sardis; 23. Miletos; 24. Didyma; 25. Halikarnassos; 26. Colchis; 27. Babylon; 28. Ur.

Map by Jessica Trelogan, Ingrid Edlund-Berry, and Beth Chichester. 


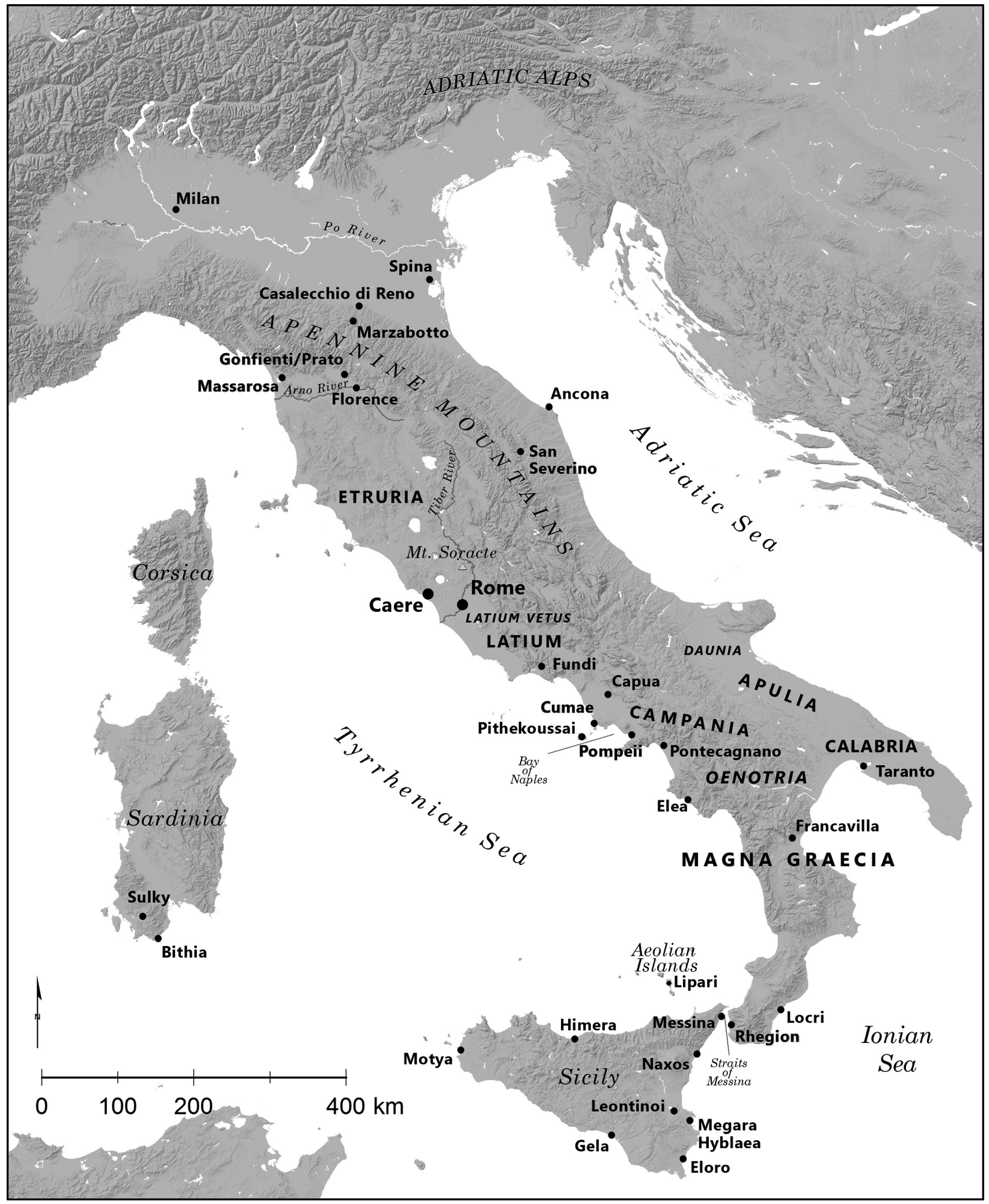

MAP 2. Italy. Map by Jessica Trelogan, Ingrid Edlund-Berry, and Beth Chichester. 


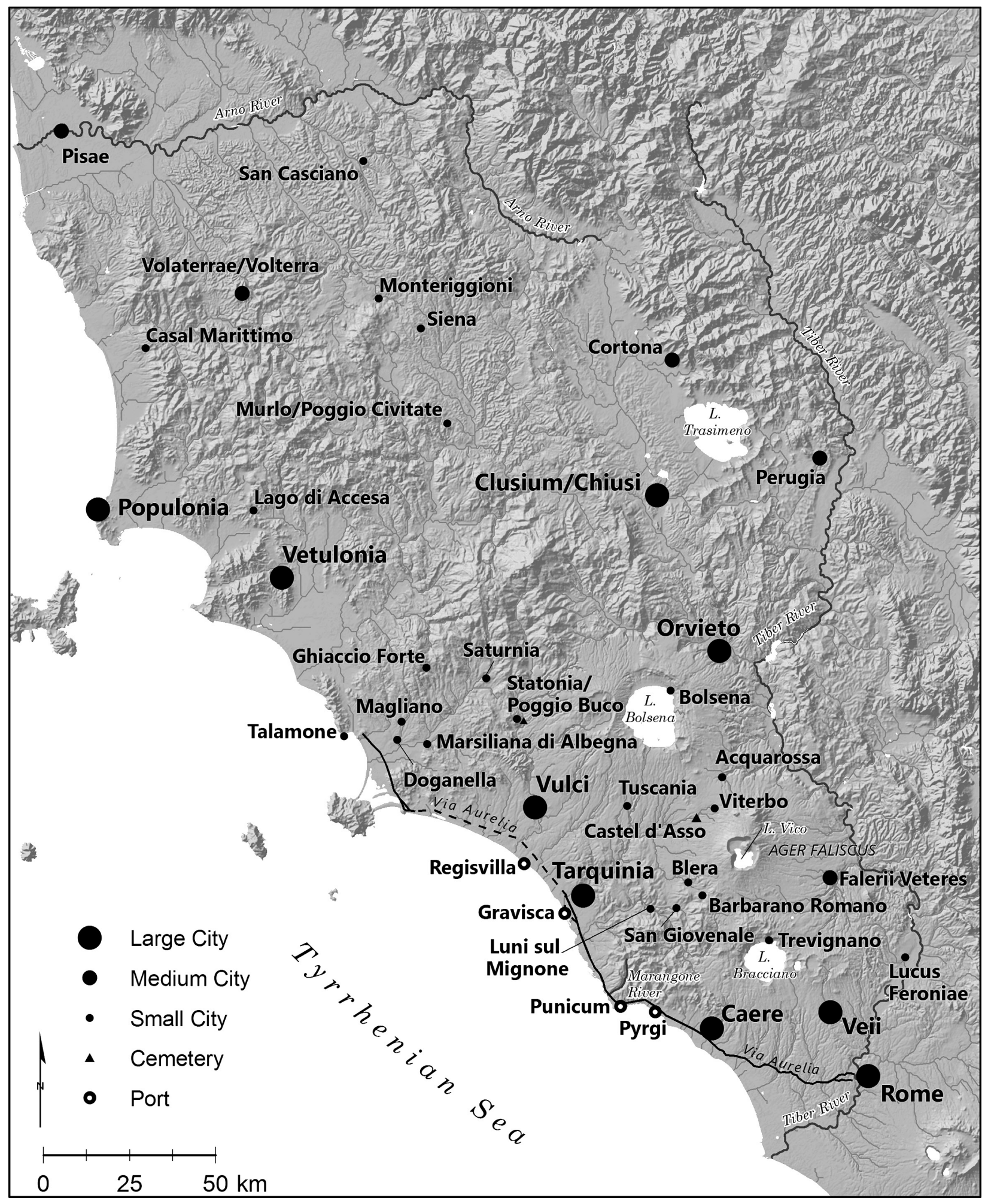

MAP 3. Etruria. Map by Jessica Trelogan, Ingrid Edlund-Berry, and Beth Chichester. 


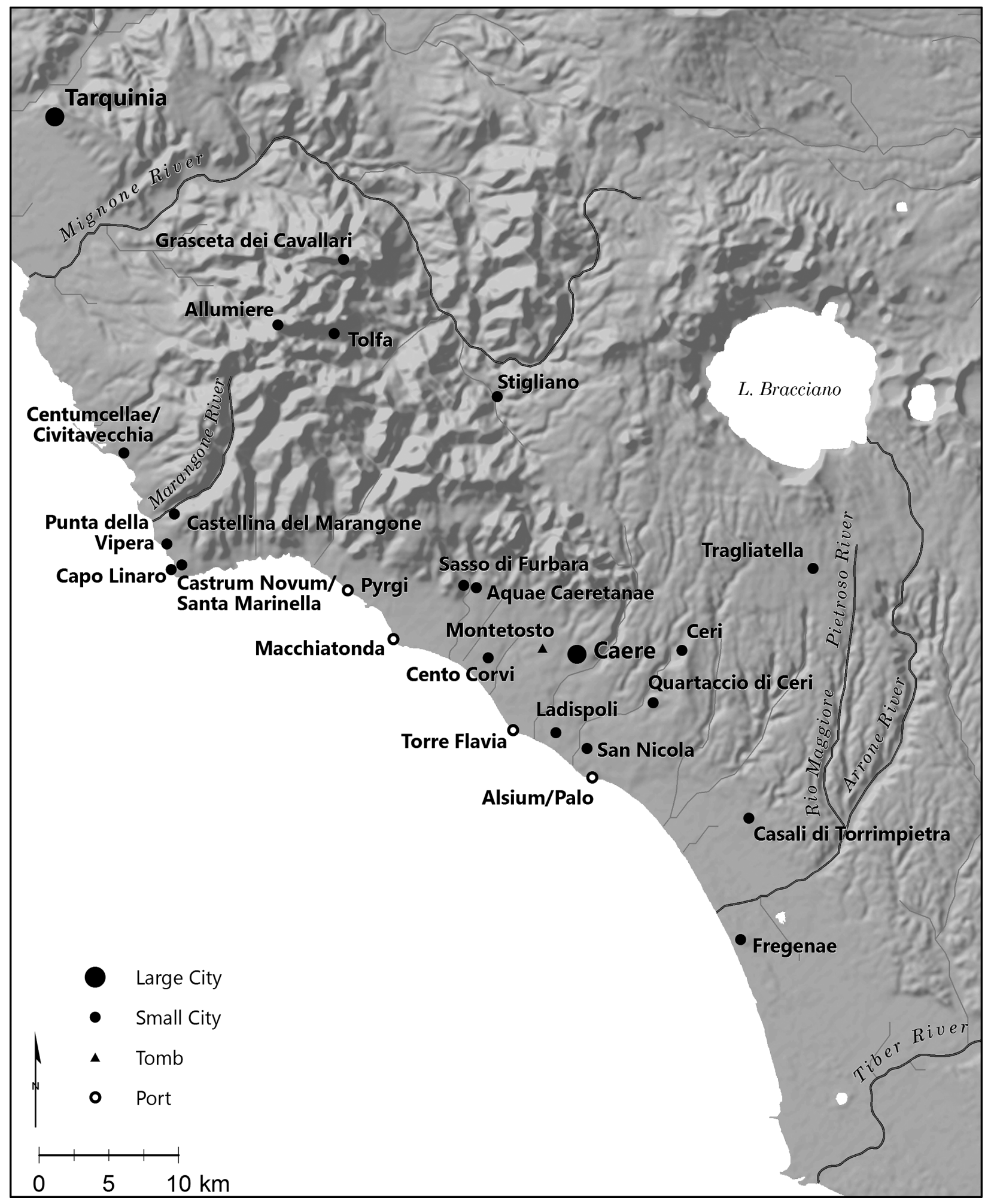

M AP 4. Territory of Caere. Map by Jessica Trelogan, Ingrid Edlund-Berry, and Beth Chichester. 


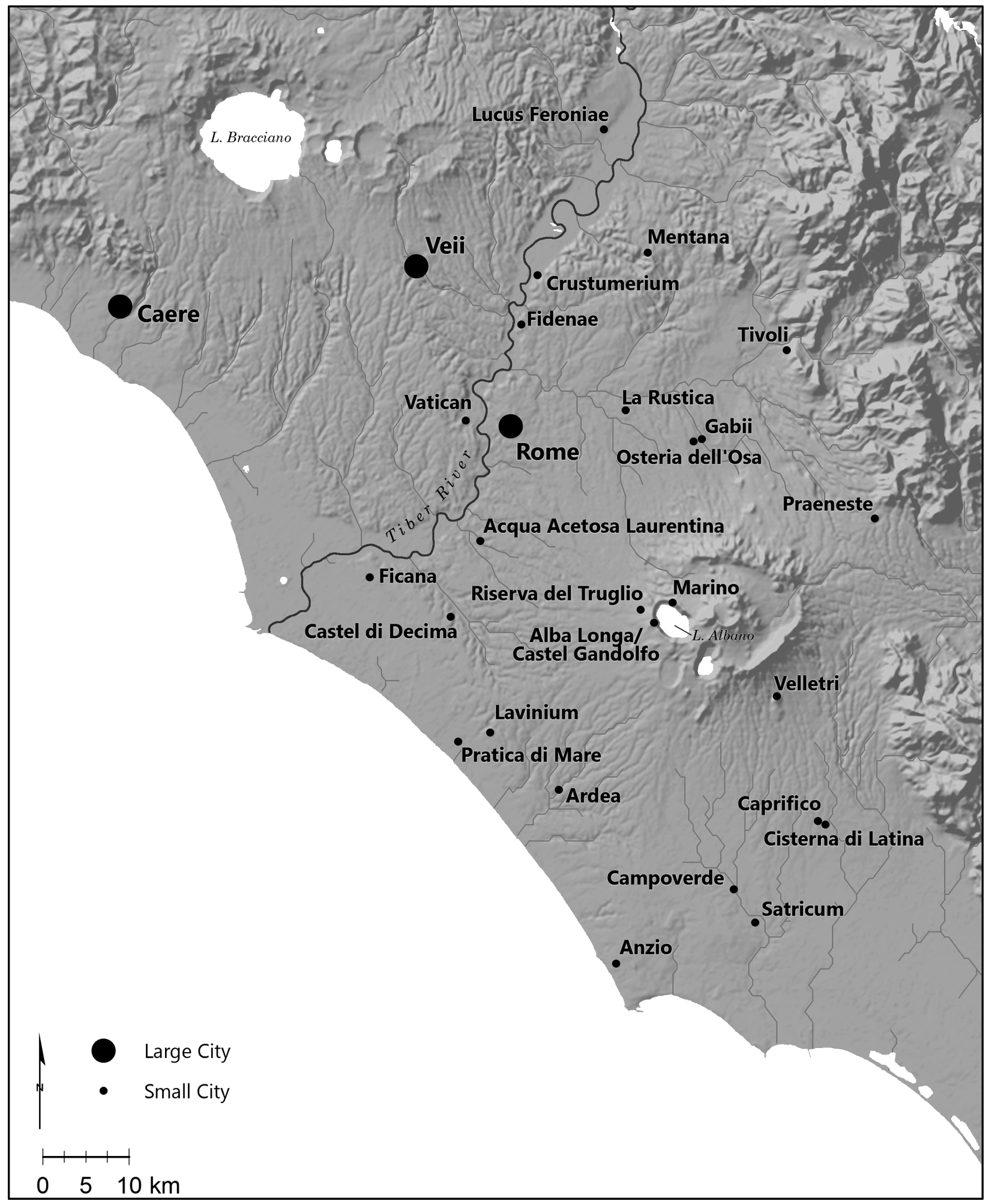

MAP 5. Latium. Map by Jessica Trelogan, Ingrid Edlund-Berry, and Beth Chichester. 


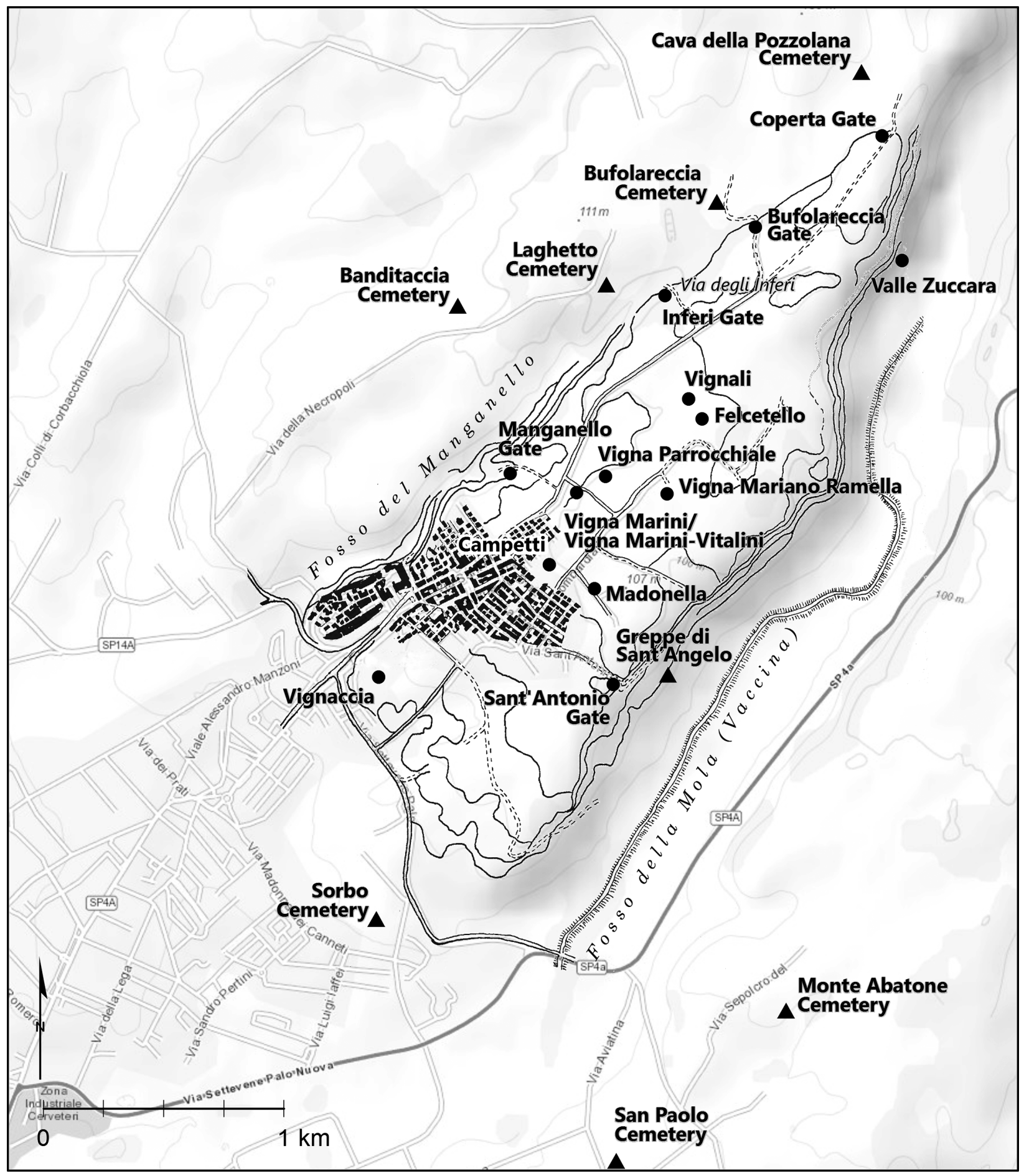

MAP 6. Caere, with surrounding necropoleis and central arteries.

Map by Jessica Trelogan, Ingrid Edlund-Berry, and Beth Chichester; map source: G. Nardi. 
THIS PAGE INTENTIONALLY LEFT BLANK 


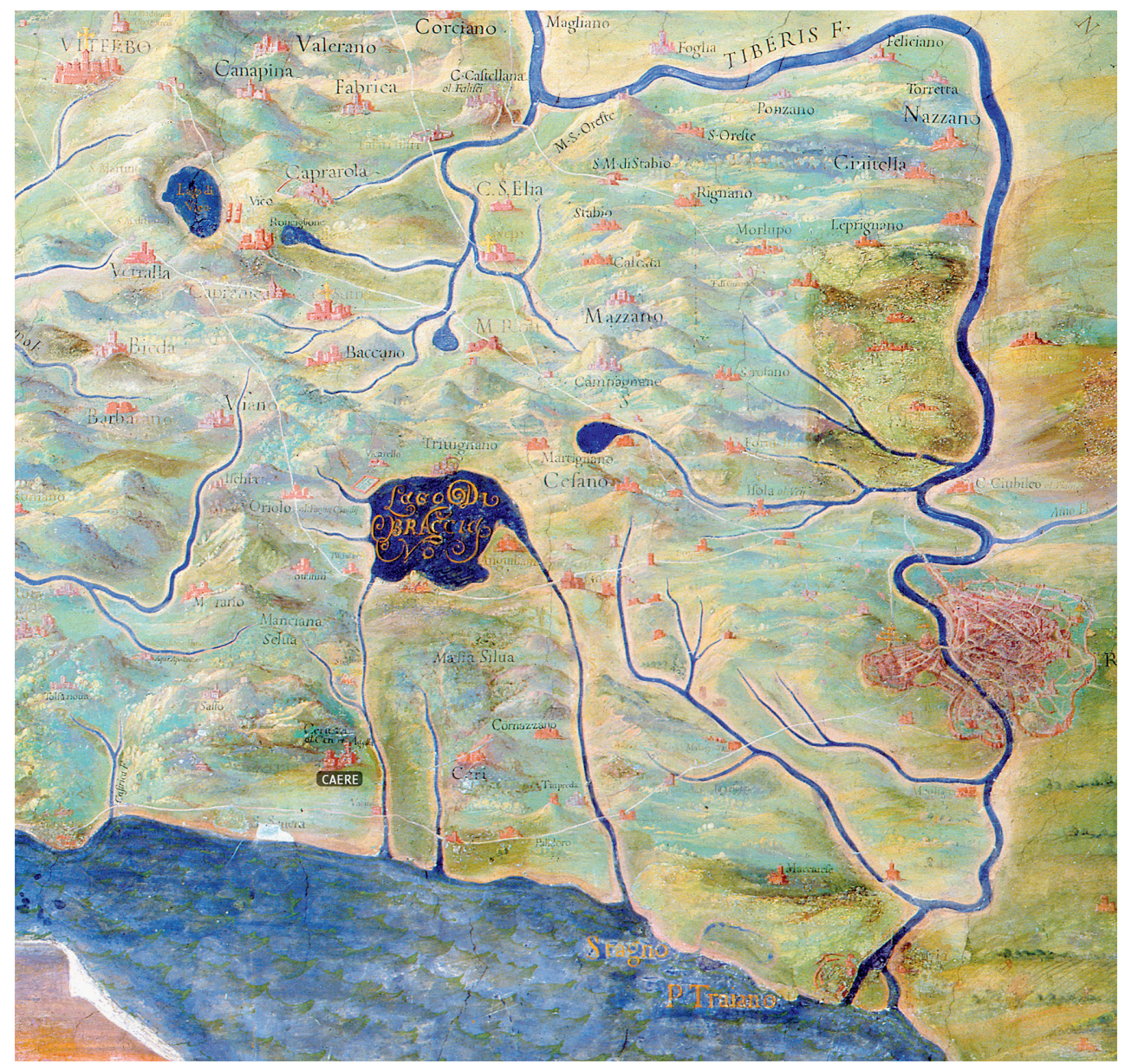

Plate I. Vatican map with Caere (1580-1583), from the Gallery of Maps, Vatican Museums. Photo () Vatican Museums.

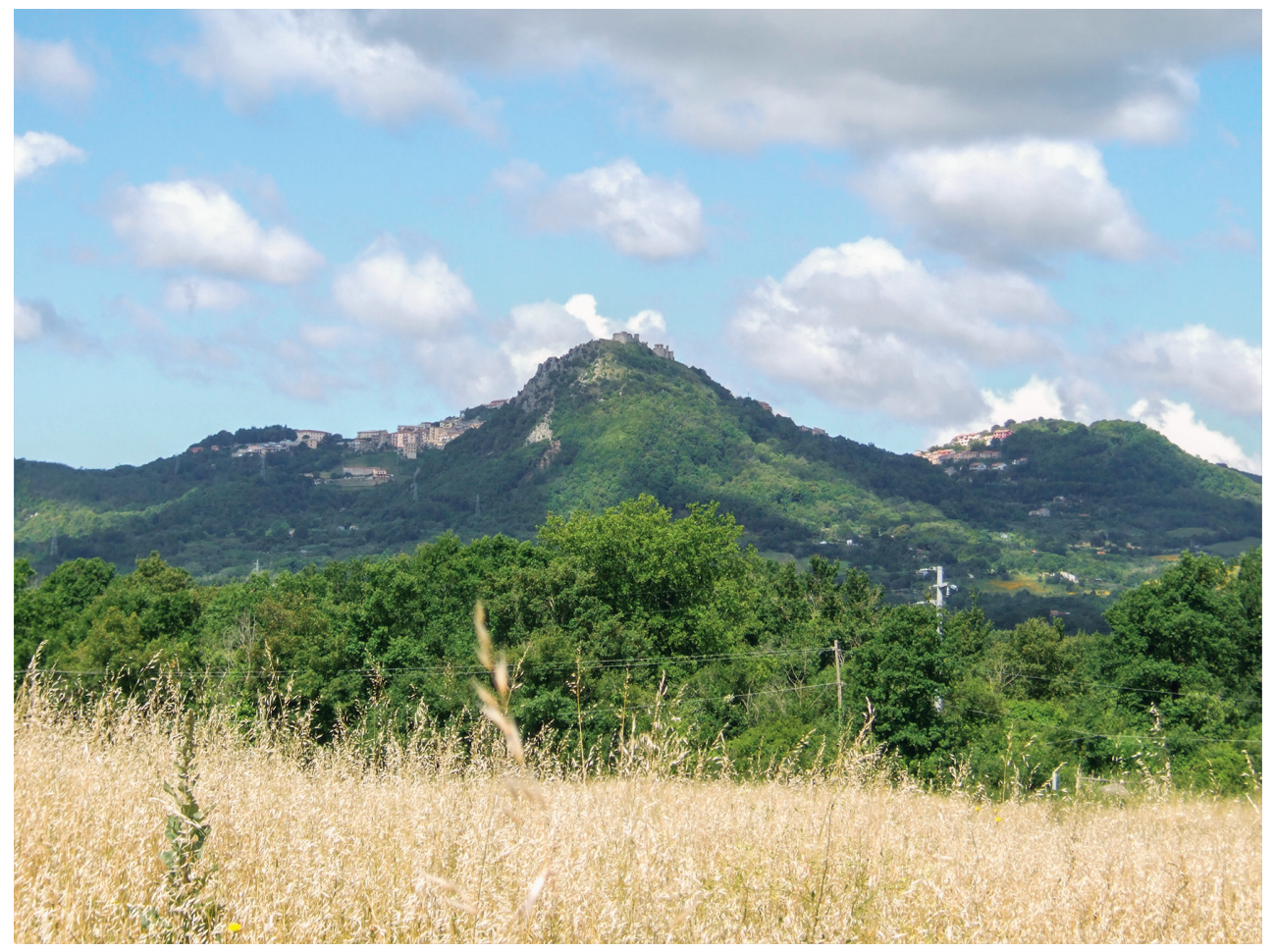

PLATE 2. Tolfa Mountains. Photo: Ingrid Edlund-Berry. 


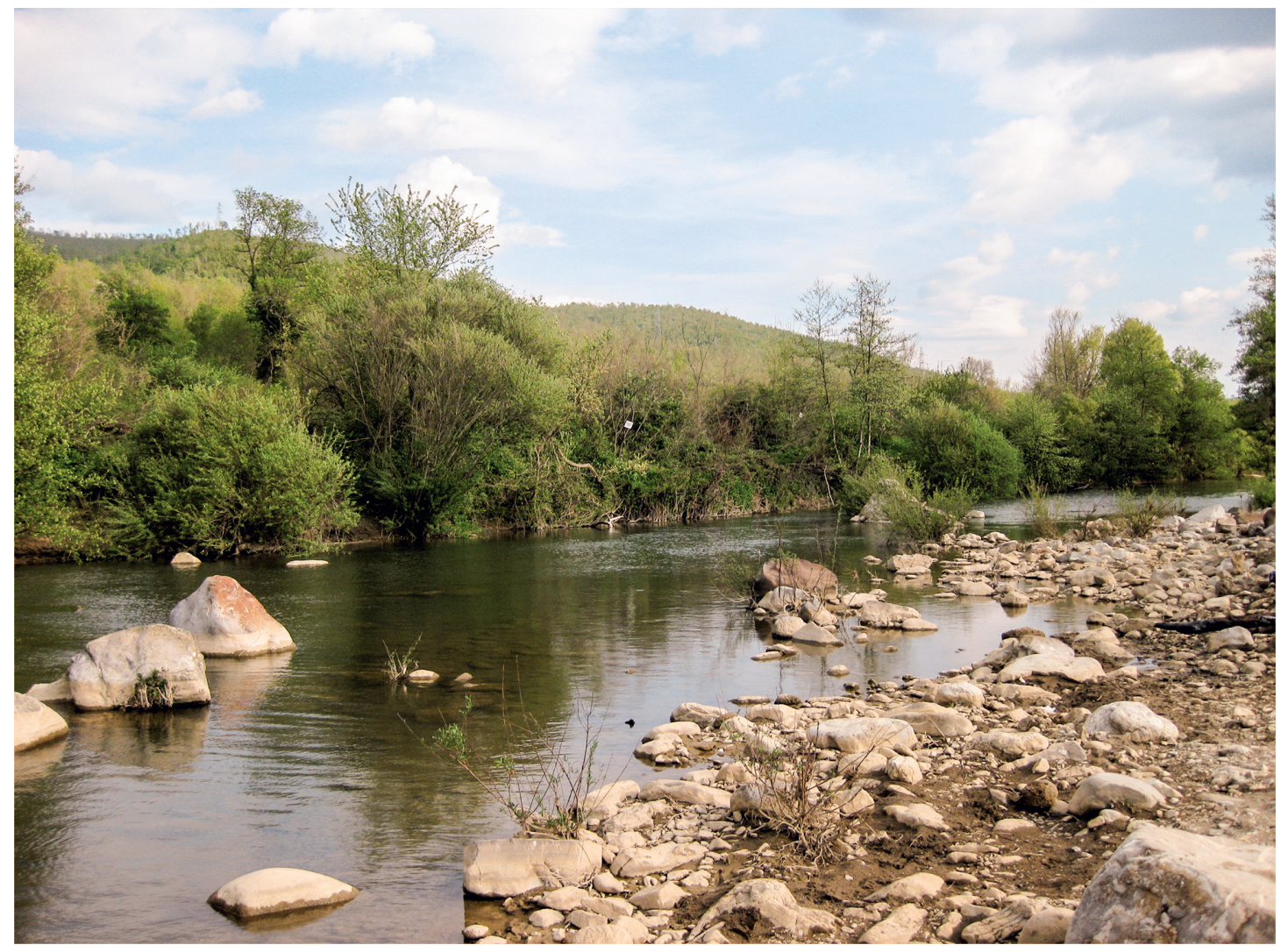

plate 3. Mignone River. Photo: Kevin Dicus.

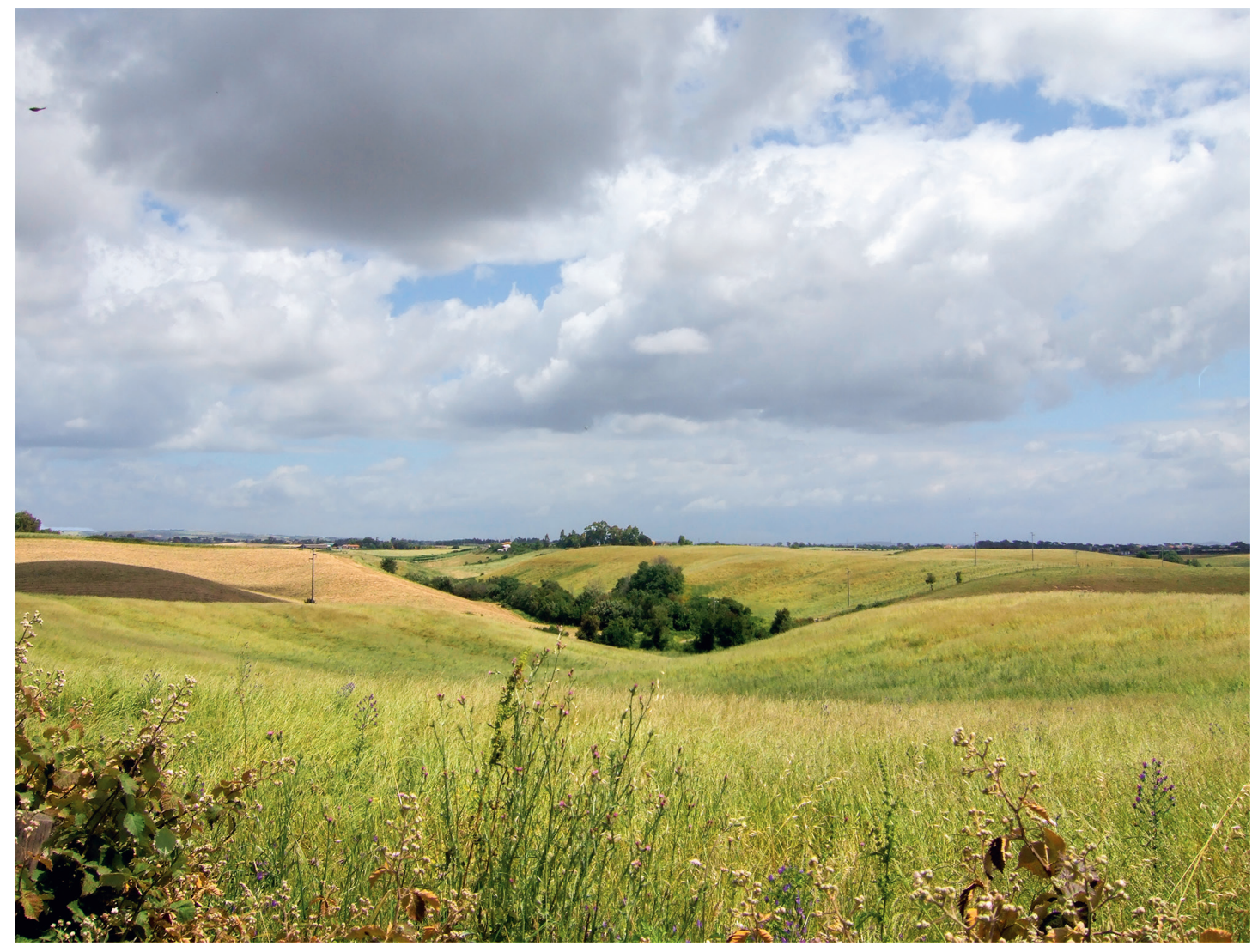

plate 4. Tragliatella. Photo: Ingrid Edlund-Berry. 

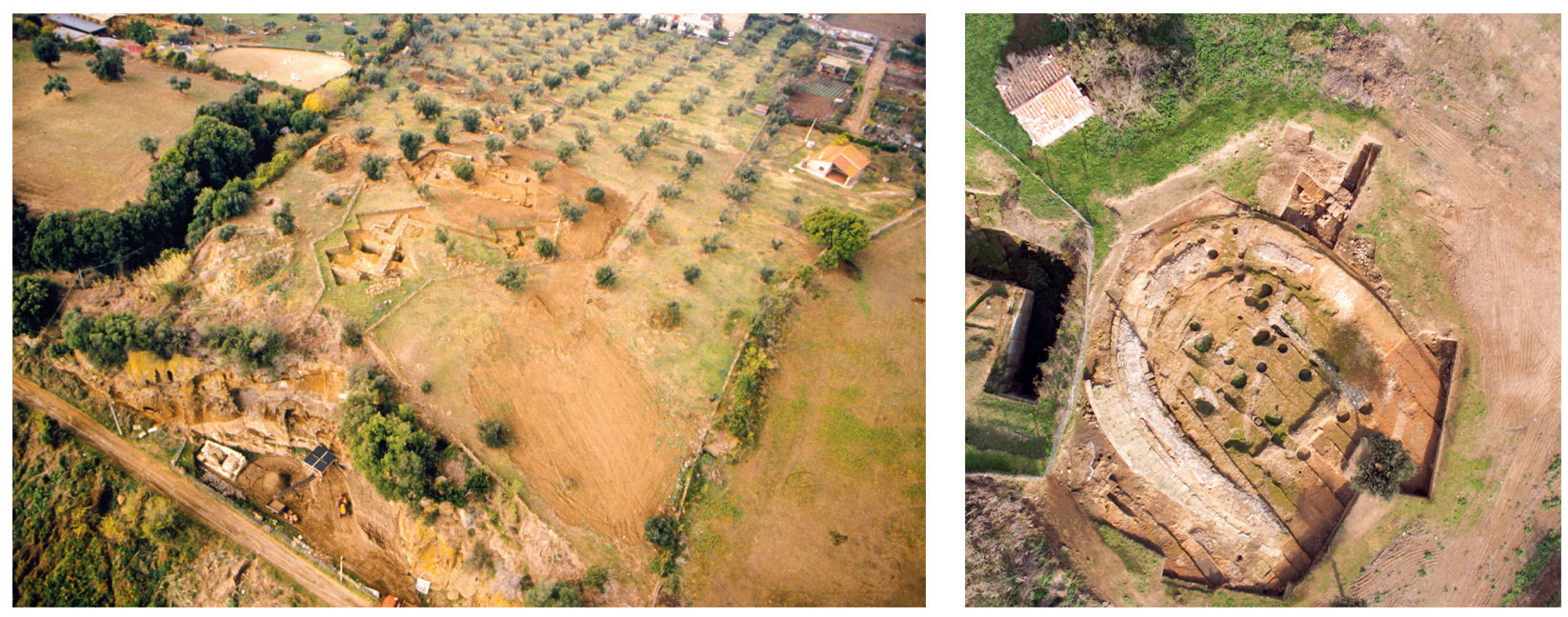

Plate 5 (left). Overview of Sant'Antonio site. CNR-ISMA Archive; photo: Marcello Bellisario.

P LATE 6 (right). The Elliptical Building at Vigna Parrocchiale. CNR-ISMA Archive; photo: Marcello Bellisario.

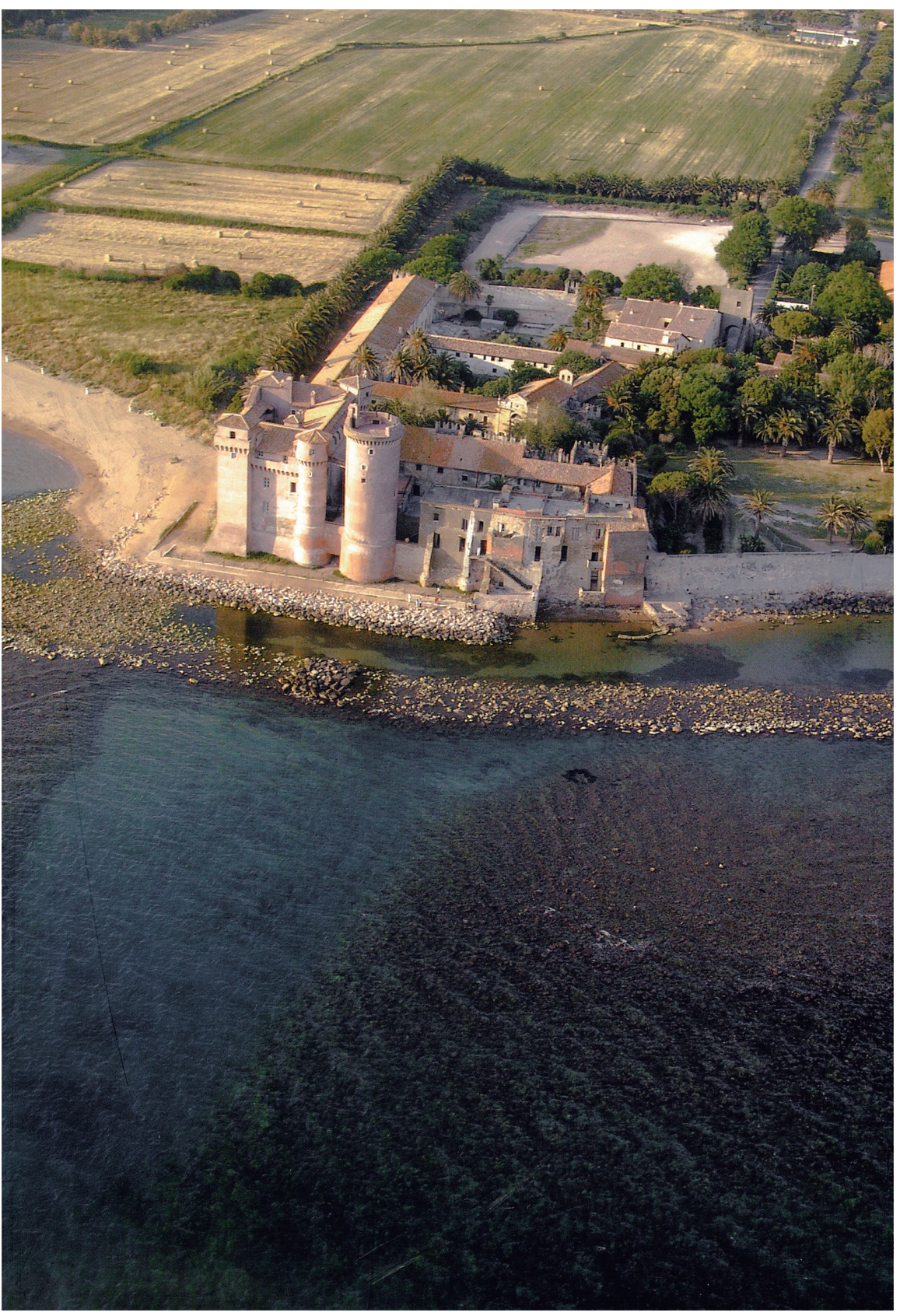

PLATE 7. The castle of Santa Severa on the site of ancient Pyrgi. The underwater channel is clearly visible on the left. After Enei 2008: fig. I8. 

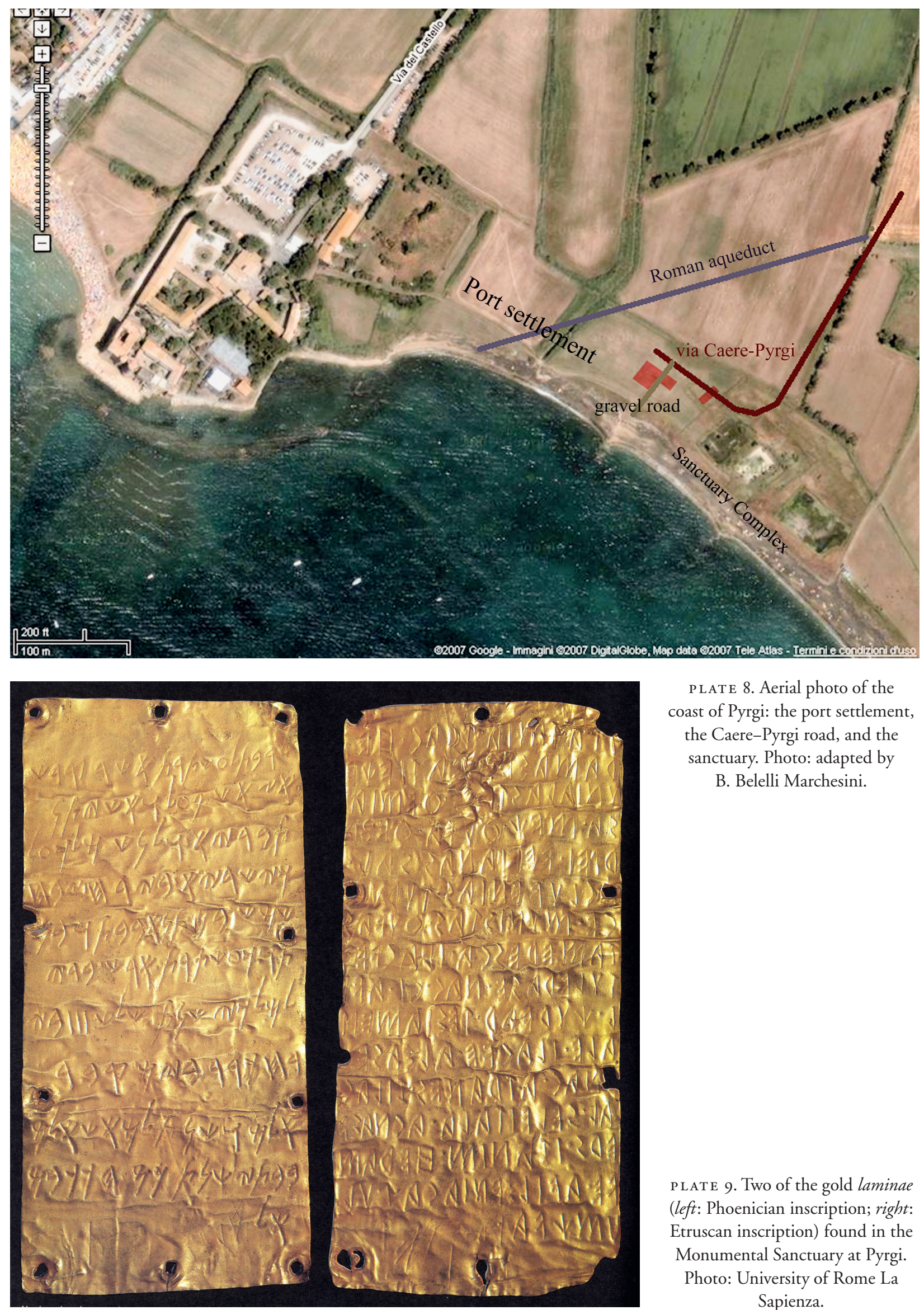

PLATE 8. Aerial photo of the coast of Pyrgi: the port settlement, the Caere-Pyrgi road, and the sanctuary. Photo: adapted by B. Belelli Marchesini.

PLATE 9. Two of the gold laminae (left: Phoenician inscription; right: Etruscan inscription) found in the Monumental Sanctuary at Pyrgi. Photo: University of Rome La Sapienza. 

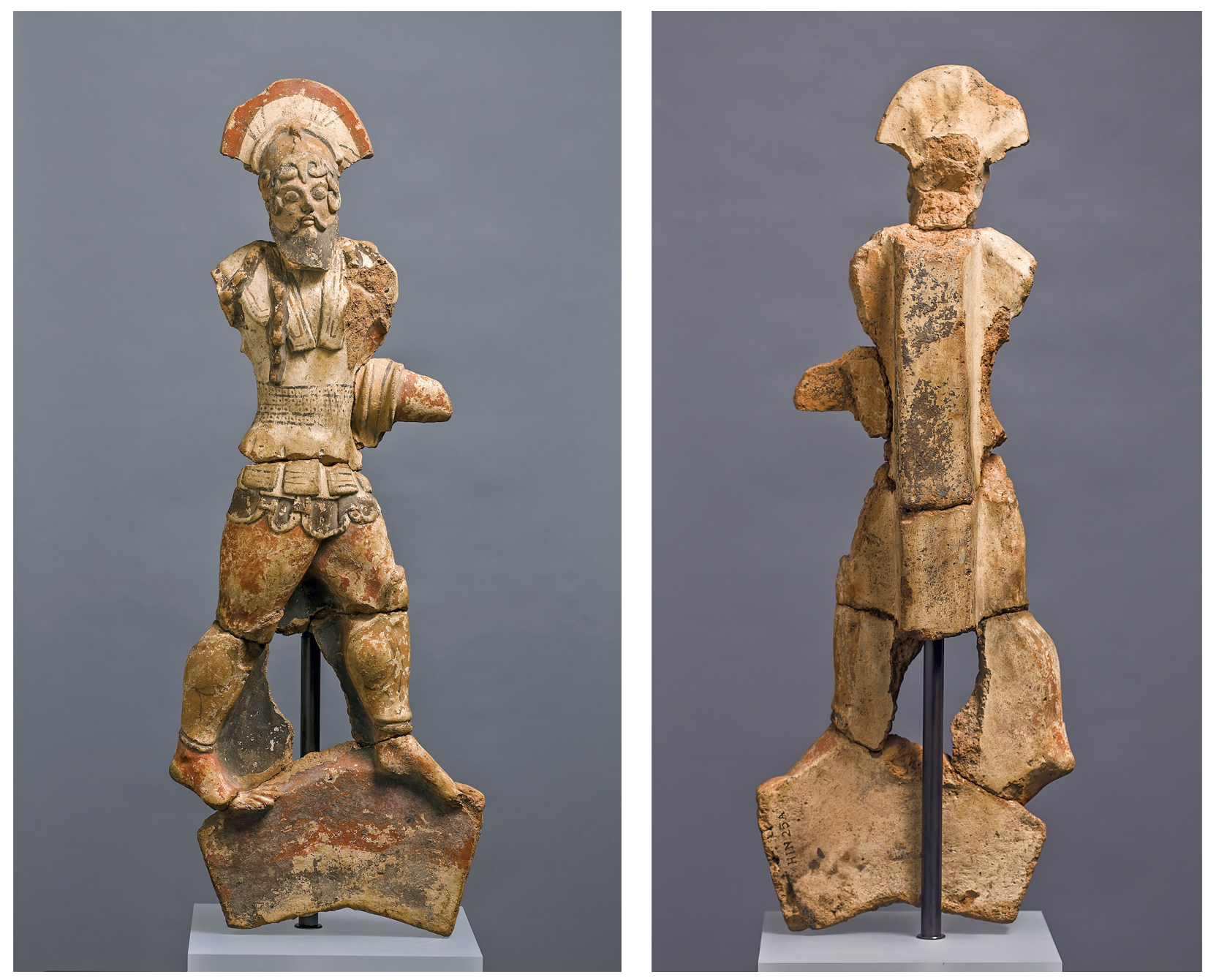

PLATE IO. Terracotta striding warrior, (a) front and (b) back. Acroterion from pediment. Vigna Marini-Vitalini. Ca. 5 Iо вCE. Ny Carlsberg Glyptotek, Copenhagen. Photo: Ole Haupt.

PLATE ir. Ceiling of the earlier tomb of the Sorbo Tumulus: Tomb of the Elevator. 675-650 BCE. Photo: A. Naso.

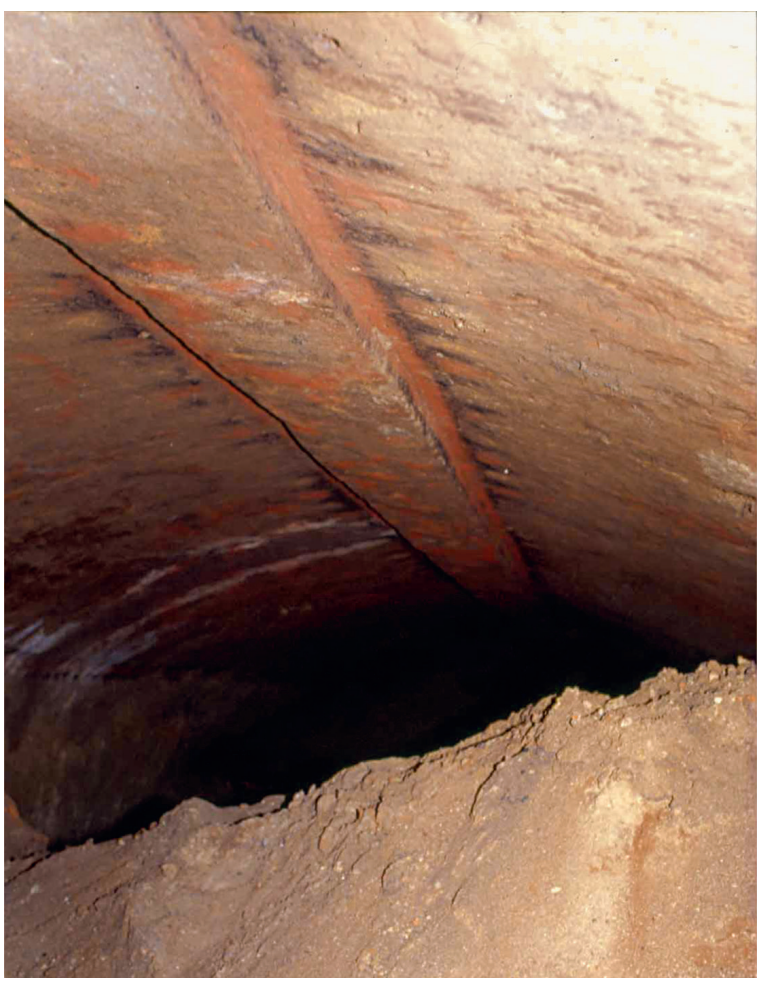




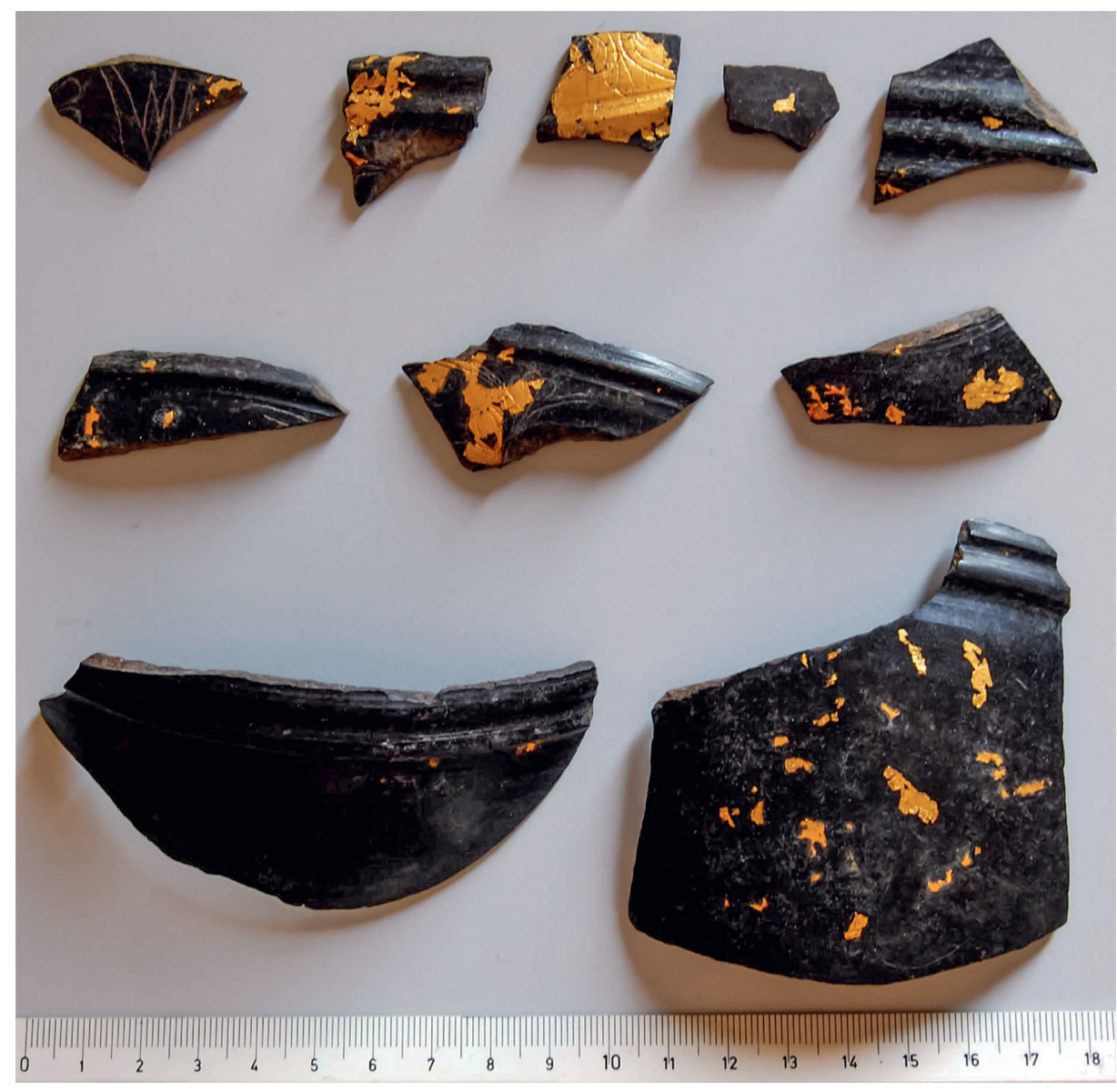

PLATE I2. Bucchero vessel, sherds with gold coating. Around 600 BCE. Museum storeroom, Cerveteri. Photo: A. Naso.

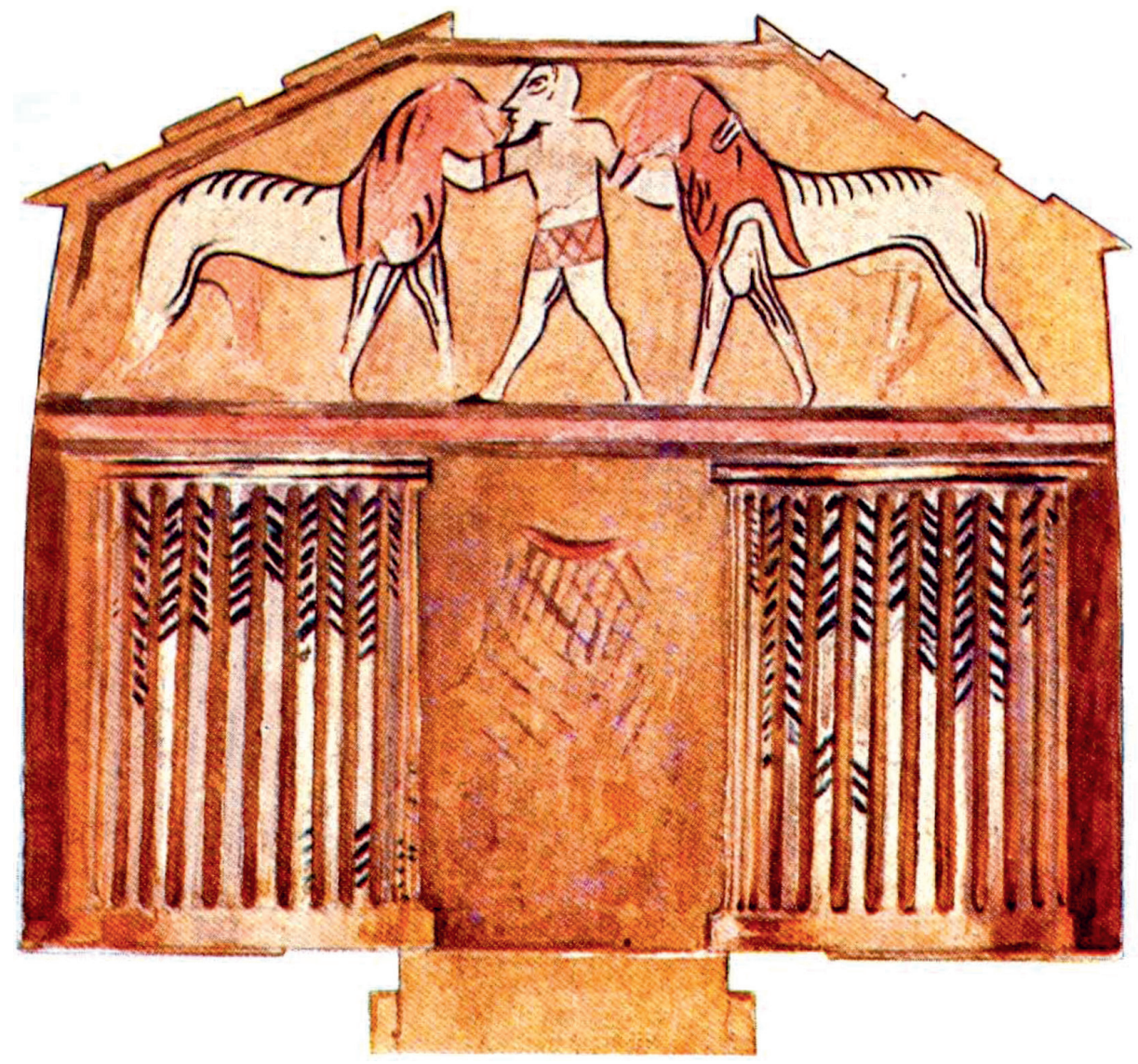

PLATE I3. Tomb of the Painted Lions (Leoni Dipinti). MonAntLinc 42 (1955): pl. 2. 
P LATE I4. Gold disc fibula. From the Regolini-Galassi Tomb. Ca. 675-650 вСE. Museo Gregoriano Etrusco, Vatican City, inv. 20552. Photo ๑ Vatican Museums.

PLATE I5. The Boccanera plaques. From a tomb in the Banditaccia cemetery. 560-550 BCE. London, British Museum. Photo (C) Trustees of the British Museum.
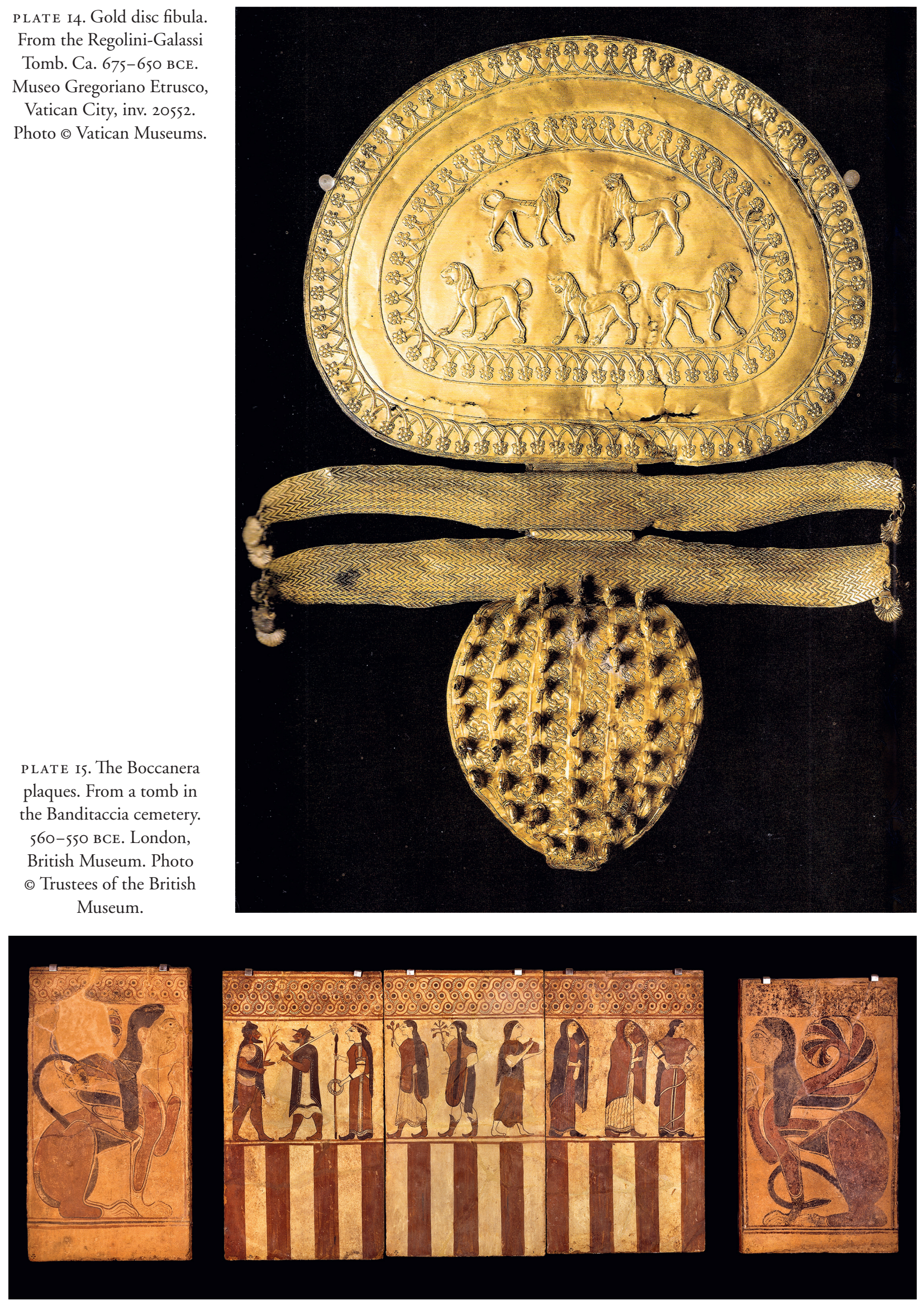


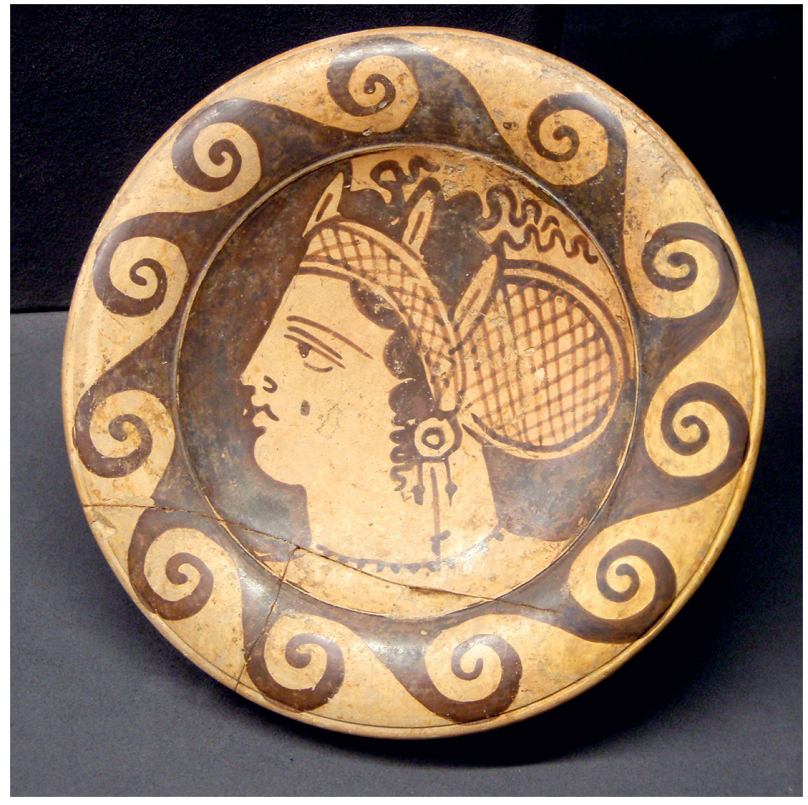

PLATE I6. Head of a woman, on the eponymous Genucilia plate in Providence, Rhode Island, with the name Poplia Genucilia painted on the underside of the foot. Perhaps discovered at Falerii Veteres. 350-325 BCE. Photo: Erik Gould; courtesy of the Museum of Art, Rhode Island School of Design, Providence.

plate 17. Painting of palm tree. Hypogeum of Clepsina. Third century BCE. Photo: Fabio Colivicchi.

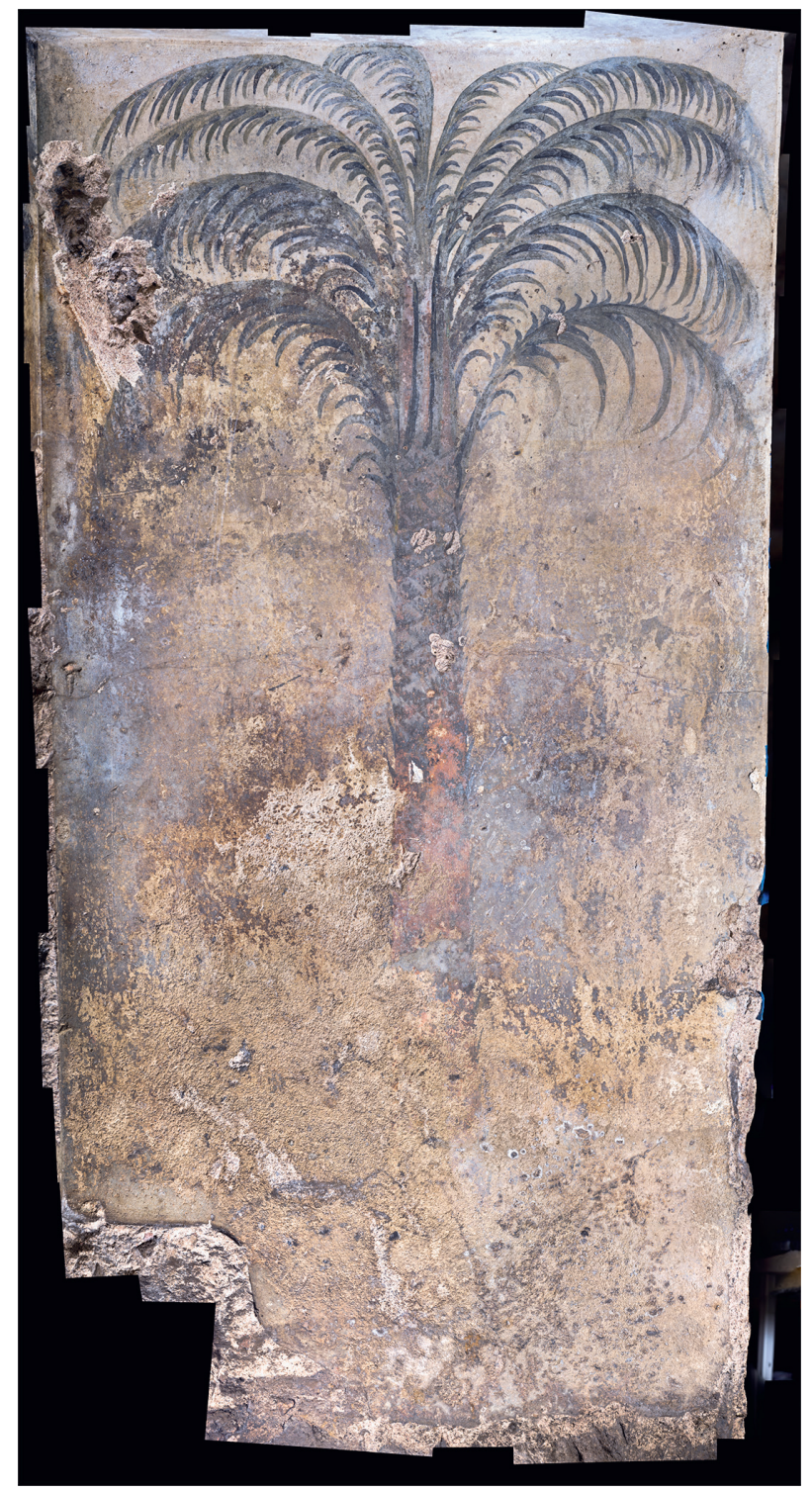


CAERE 
THIS PAGE INTENTIONALLY LEFT BLANK 